\title{
Fracture, Fatigue, and Structural Integrity of Metallic Materials
}

\author{
Sergio Cicero * (D) and José Alberto Álvarez \\ LADICIM (Laboratory of Materials Science and Engineering), University of Cantabria, E.T.S. de Ingenieros de \\ Caminos, Canales y Puertos, Av/Los Castros 44, 39005 Santander, Spain \\ * Correspondence: ciceros@unican.es; Tel.: +34-942200917
}

Received: 15 August 2019; Accepted: 20 August 2019; Published: 20 August 2019

check for updates

\section{Introduction and Scope}

Fracture, fatigue, and other subcritical processes, such as creep crack growth or stress corrosion cracking, present numerous open issues from both scientific and industrial points of view. These phenomena are of special interest in industrial and civil metallic structures, such as pipes, vessels, machinery, aircrafts, ship hulls, and bridges, given that their failure may imply catastrophic consequences for human life, the natural environment and/or the economy. Moreover, an adequate management of their operational life, defining suitable inspection periods, repairs, or replacements, requires their safety or unsafety conditions to be defined.

The analysis of these technological challenges requires accurate comprehensive assessments tools based on solid theoretical foundations, as well as structural integrity assessment standards or procedures incorporating such tools into industrial practice.

This Special Issue is focused on new advances in fracture, fatigue, creep and corrosion analysis of metallic structural components containing defects (e.g., cracks, notches, metal loss, etc.), and also on those developments that are being or could be incorporated to structural integrity assessment procedures.

\section{Contributions}

Twelve research contributions (eleven articles and one communication) have been published in this Special Issue. Eleven contributions deal with critical or subcritical phenomena, and one is related to non-destructive inspections. Among the former, six of them provide significant advances on fatigue research, three of them deal with the analysis of hydrogen issues and their effect on the mechanical behavior, and two are related to the fracture analysis of notches.

Thus, in the fatigue context, Yao et al. [1] analyze the fatigue behavior of aluminum foam sandwich panels fabricated through liquid diffusion welding and adhesive methods, also providing microstructural and metallurgical analyses; Chen et al. [2] investigate the fatigue behavior of a given steel bridge deck by characterizing (experimentally) the fatigue performance of the deck plates and the deck welded details, and performing stress analysis. Hardy and DuQuesnay [3] characterize the fatigue performance of hi-lok fasteners used in aircraft structural joints and subjected to multiple collar replacements, as well as the corresponding behavior under static loading conditions. Wang et al. [4] provide predictions of the fatigue life of Inconel 690 steam generator tubes by using tubular specimens containing holes. Leitner et al. [5] analyze how overloads induce fatigue crack growth retardation on EA47 steel round bars containing semi-elliptical cracks, comparing the experimental results to the predictions provided by a modified NASGRO equation. Finally, Fueki et al. [6] evaluates the fatigue limit improvement caused by needle peening in high tensile (strength) steel HT780. All these contributions cover different sectors, such as aerospace, railway, bridge design, or energy generation, among others. 
The three contributions related to hydrogen research start with Arroyo et al. [7], who provide a new methodology to analyze subcritical Hydrogen Induced Cracking by using Failure Assessment Diagrams, a tool that is commonly used in fracture-plastic collapse structural integrity assessments. Then, Kim et al. [8] study the role of diffusible hydrogen on delayed fractures in hot-stamped ultrahigh strength steels used in automotive structural components, and analyze how baking times and temperatures affect the cracking behavior. Lastly, González et al. [9] analyze the Environmentally Assisted Cracking (Hydrogen Embrittlement) behavior of two steels containing notch-type defects. Their analysis is based on the Theory of Critical Distances, a theory that had only been used to analyze fracture and fatigue phenomena.

Finally, the two contributions related to the fracture analysis of notch-type defects are those provided by Torabi et al. [10] and Cicero et al. [11], respectively. The former investigates, by using Finite Fracture Mechanics and the Equivalent Material Concept, the ductile fracture initiation of two aluminum alloys containing different notch types. The latter provides default values of the critical distance for structural steels operating at their corresponding Lower Shelf and Ductile-to-Brittle Transition Zone, and provides formulation for the apparent fracture toughness estimation of such steels when containing U-shaped notches.

The final contribution [12] is a communication that examines the feasibility of applying synchrotron radiation $\mu \mathrm{CT}$ imaging for non-destructive inspection of inclusions in alloy steels.

\section{Conclusions and Outlook}

The contributions of this Special Issue provide different advances in fracture, fatigue, and structural integrity research. Their application affects a number of engineering sectors, such as aerospace, mechanical, civil, railway, materials, and energy, among others. Evidently, there are still numerous open issues to solve in this context, and engineering applications still need to be more developed and improved, but as guest editors, we hope this Special Issue provides a significant impact and also that the scientific and engineering communities found it interesting.

Finally, we would like to thank all the authors for their contributions, and all the reviewers for their outstanding efforts to improve the scientific quality of the different documents composing this this Special Issue. We would also like to give special thanks to all the staff at the Metals Editorial Office, especially to Betty Jin, who managed and simplified the publication process.

Conflicts of Interest: The authors declare no conflicts of interest.

\section{References}

1. Yao, C.; Hu, Z.; Mo, F.; Wang, Y. Fabrication and Fatigue Behavior of Aluminum Foam Sandwich Panel via Liquid Diffusion Welding Method. Metals 2019, 9, 582. [CrossRef]

2. Chen, Y.; Lv, P.; Li, D. Research on Fatigue Strength for Weld Structure Details of Deck with U-rib and Diaphragm in Orthotropic Steel Bridge Deck. Metals 2019, 9, 484. [CrossRef]

3. Hardy, D.F.; DuQuesnay, D.L. Effect of Repetitive Collar Replacement on the Residual Strength and Fatigue Life of Retained Hi-Lok Fastener Pins. Metals 2019, 9, 445. [CrossRef]

4. Wang, Q.; Chen, J.; Chen, X.; Gao, Z.; Li, Y. Fatigue Life Prediction of Steam Generator Tubes by Tube Specimens with Circular Holes. Metals 2019, 9, 322. [CrossRef]

5. Leitner, M.; Simunek, D.; Maierhofer, J.; Gänser, H.P.; Pippan, R. Retardation of Fatigue Crack Growth in Rotating Bending Specimens with Semi-Elliptical Cracks. Metals 2019, 9, 156. [CrossRef]

6. Fueki, R.; Takahashi, K.; Handa, M. Fatigue Limit Improvement and Rendering Defects Harmless by Needle Peening for High Tensile Steel Welded Joint. Metals 2019, 9, 143. [CrossRef]

7. Arroyo Martínez, B.; Álvarez Laso, J.A.; Gutiérrez-Solana, F.; Cayón Martínez, A.; Jirón Martínez, Y.J.; Seco Aparicio, A.R. A Proposal for the Application of Failure Assessment Diagrams to Subcritical Hydrogen Induced Cracking Propagation Processes. Metals 2019, 9, 670. [CrossRef]

8. Kim, H.J.; Park, H.K.; Lee, C.W.; Yoo, B.G.; Jung, H.Y. Baking Effect on Desorption of Diffusible Hydrogen and Hydrogen Embrittlement on Hot-Stamped Boron Martensitic Steel. Metals 2019, 9, 636. [CrossRef] 
9. González, P.; Cicero, S.; Arroyo, B.; Álvarez, J.A. Environmentally Assisted Cracking Behavior of S420 and X80 Steels Containing U-notches at Two Different Cathodic Polarization Levels: An Approach from the Theory of Critical Distances. Metals 2019, 9, 570. [CrossRef]

10. Torabi, A.R.; Berto, F.; Sapora, A. Finite Fracture Mechanics Assessment in Moderate and Large Scale Yielding Regimes. Metals 2019, 9, 602. [CrossRef]

11. Cicero, S.; Fuentes, J.D.; Procopio, I.; Madrazo, V.; González, P. Critical Distance Default Values for Structural Steels and a Simple Formulation to Estimate the Apparent Fracture Toughness in U-Notched Conditions. Metals 2018, 8, 871. [CrossRef]

12. Shimamura, Y.; Matsushita, S.; Fujii, T.; Tohgo, K.; Akita, K.; Shobu, T.; Shiro, A. Feasibility Study on Application of Synchrotron Radiation $\mu \mathrm{CT}$ Imaging to Alloy Steel for Non-Destructive Inspection of Inclusions. Metals 2019, 9, 527. [CrossRef]

(C) 2019 by the authors. Licensee MDPI, Basel, Switzerland. This article is an open access article distributed under the terms and conditions of the Creative Commons Attribution (CC BY) license (http://creativecommons.org/licenses/by/4.0/). 